\title{
Nilai-Nilai Kearifan Lokal Masyarakat Suku Anak Dalam Pada Karnaval Hari Kemerdekaan di Kecamatan Renah Pamenang Kabupaten Merangin Jambi
}

\author{
Wenny Dewantari ${ }^{1}$, Trisna Sukmayadi ${ }^{2}$ \\ ${ }^{1}$ Program Studi PPKn, Universitas Ahmad Dahlan, Yogyakarta \\ ${ }^{2}$ Program Studi PPKn, Universitas Ahmad Dahlan, Yogyakarta \\ ${ }^{1}$ wenny1500009027@webmail.uad.ac.id, ${ }^{2}$ trisnasukmayadi@ppkn.uad.ac.id
}

\begin{abstract}
Abstrak
Konflik keberagaman di Indonesia, lunturnya nilai-nilai kearifan lokal masyarakat Indonesia, serta terjadi degradasi sikap nasionalisme dan cinta tanah air marak terjadi akhir-akhir ini. Namun, masih ada sebagian masyarakat yang memiliki rasa nasionalisme serta memegang teguh nilai-nilai kearifan lokal yang mereka miliki. Salah satunya ialah masyarakat Suku Anak Dalam. Penelitian ini bertujuan untuk untuk mengetahui nilai-nilai kearifan lokal masyarakat Suku Anak Dalam pada karnaval Hari Kemerdekaan di Kecamatan Renah Pamenang, Kabupaten Merangin, Jambi. Penelitian ini menggunakan pendekatan kualitatif dengan jenis penelitian studi kasus. Alasan penggunaan metode penelitian ini karena menyesuaikan dengan tujuan pokok penelitian. Pengambilan data dilakukan dengan melakukan kegiatan wawancara dan dokumentasi. Hasil penelitian menunjukan bahwa kearifan lokal masyarakat Suku Anak Dalam di Kecamatan Renah Pamenang tercermin dalam bentuk kebiasaan/ cara hidup yang mereka lakukan, pakaian yang mereka kenakan, pandangan hidup, serta aturan dan larangan yang ada. Nilai kearifan lokal masyarakat yang tercermin pada kegiatan karnaval Hari Kemerdekaan Republik Indonesia di Kecamatan Renah Pamenang adalah nilai spiritual, nilai moral dan kesopanan, nilai kesederhanaan/ efisiensi, nilai keteguhan dan ketaatan, nilai gotong royong dan solidaritas, nilai cinta lingkungan, nilai kemanfaatan, nilai kesadaran hukum, dan nilai cinta tanah air.
\end{abstract}

Kata Kunci: Nilai Kearifan Lokal, Kearifan Lokal, Suku Anak Dalam, Renah Pamenang, Karnaval Hari Kemerdekaan

\begin{abstract}
Conflicts of diversity in Indonesia, the fading of the values of local wisdom of the Indonesian people, as well as the degradation of nationalism and patriotism occurred lately. However, there are still some people who have a sense of nationalism and uphold the values of local wisdom that they have. One of them is the Anak Dalam Tribe community. This study aims to determine the values of local wisdom of the Anak Dalam Tribe community on the Independence Day carnival in the District of Renah Pamenang, Merangin Regency, Jambi. This study uses a qualitative approach to the type of case study research. The reason for using this research method is because it adjusts to the main objectives of the study. Data is collected by conducting interviews and documentation. The results showed that the local wisdom of the Anak Dalam Tribe community in Renah Pamenang District was reflected in the form of their habits / way of life, the clothes they wore, the way of life, and the rules and prohibitions. The values of local wisdom that are reflected in the carnival activities of the Republic of Indonesia's Independence Day in Renah Pamenang District are spiritual values, moral values and politeness, values of simplicity / efficiency, values of determination and obedience, values of mutual cooperation and solidarity, values of environmental care, values of benefit, values of benefit, values legal awareness, and the value of patrio.
\end{abstract}

Keywords: Value of Local Wisdom, Local Wisdom, Suku Anak Dalam, Renah Pamenang, Independence Day Carnival

\section{Pendahuluan}

Indonesia merupakan negara multikultur. Hal ini dibuktikan dengan keberagaman yang ada di Indonesia, mulai dari keragaman suku, agama, ras, budaya, serta keberagaman yang lainnya. Seiring dengan berkembangnya teknologi dan informasi, tidak dapat dipungkiri bahwa nilai-nilai budaya yang ada terus menemui hambatannya. Menurut Anas (2015), di berbagai daerah di Indonesia sekarang, banyak sekali budaya-budaya asli tiap daerah yang mulai luntur. Misalnya saja, di Desa Rai-oi, Kecamatan Sape, Kabupaten Bima, NTB. Kebudayaan asli di Desa Rai-oi semakin hari semakin terkikis oleh berkembangnya arus globalisasi yang banyak menawarkan kebudayaan-kebudayaan baru yang tak jarang menjurus kearah yang negatif. Kebudayaan seperti kesenian (tari-tarian, pakaian adat, dan lain-lain) kini sudah jarang ditemukan. Masyarakat cenderung lebih mengikuti "trend" masa kini 4 serta bergaya hidup 
"hedonis" (mengutamakan kesenangan sementara) tanpa mengindahkan nilai, tradisi serta budaya yang sudah lama tumbuh dan berkembang di masyarakat. Tidak hanya terbatas pada budaya saja, akan tetapi kearifan lokal yang merupakan pandangan hidup serta menjadi ciri khas dari masyarakat di Desa Rai-oi juga ikut tergerus oleh masuknya budaya modernisasi, liberalisasi dan westernisasi.

Fenomena tersebut tentu tidak terjadi pada semua masyarakat Indonesia secara keseluruhan. Masih ada sebagian masyarakat yang memiliki rasa nasionalisme serta memegang teguh nilai-nilai kearifan lokal yang mereka miliki. Salah satunya ialah masyarakat Suku Anak Dalam yang berada di Kecamatan Renah Pamenang, Kabupaten Merangin, Jambi. Menurut Baharudin (2010), masyarakat Suku Anak Dalam merupakan salah satu suku di Indonesia yang sumber filosofi hidupnya adalah hutan. Suku Anak Dalam atau Orang Rimba biasa hidup secara nomaden (berpindah), namun ada juga yang telah bermukim membaur bersama penduduk sekitar (menetap).

Salah satu nilai kearifan lokal masyarakat Suku Anak Dalam adalah dengan partisipasi mereka saat merayakan peringatan Hari Kemerdekaan Indonesia ke-73 dengan melaksanakan upacara kemerdekaan bersama penduduk sekitar. Tidak hanya itu, mereka juga mengikuti serangkaian acara yang diadakan panitia, seperti acara karnaval. Pemerintah Kecamatan Renah Pamenang berusaha mengajak masyarakat suku untuk lebih terbuka kepada penduduk sekitar dengan tanpa menghilangkan kekhasan mereka. Dari berbagai latar belakang masalah yang ada, maka penulis akan melakukan penelitian yang berjudul "Studi Tentang Nilai-Nilai Kearifan Lokal Masyarakat Suku Anak Dalam pada Karnaval Hari Kemerdekaan di Kecamatan Renah Pamenang, Kabupaten Merangin, Jambi”.

\section{Metode}

Jenis penelitian yang digunakan penulis ialah kualitatif. Alasan penggunaan metode penelitian ini karena menyesuaikan dengan tujuan pokok penelitian, yaitu mengungkap bagaimana nilai-nilai kearifan lokal masyarakat Suku Anak Dalam pada karnaval Hari Kemerdekaan di Kecamatan Renah Pamenang. Untuk mencapai tujuan tersebut harus menggunakan data yang aktual mengenai keterikatan obyek dan subyek serta fenomena yang ada, sehingga metode penelitian kualitatif menjadi metode yang sesuai untuk penelitian ini. Selain itu, metode penelitian ini dipilih sebab penelitian ini berorientasi pada penelitian lapangan, yaitu masyarakat Suku Anak Dalam. Peneliti harus terjun ke lapangan untuk mendapatkan datadata yang dibutuhkan untuk menjawab permasalahan dalam penelitian ini.

Jenis penelitian yang dilakukan adalah dengan studi kasus. Peneliti menggunakan jenis penelitian ini sebab penelitian yang akan dilakukan mengharuskan peneliti untuk menganalisis permasalahan yang ada secara mendalam dan rinci, dengan berbagai nara sumber yang ada, dalam hal ini subyek yang terlibat pada pelaksanaan karnaval.Alasan lain penggunaan jenis penelitian ini karena kasus yang diteliti terfokus pada kekhasan nilai-nilai kearifan lokal masyarakat Suku Anak Dalam yang tidak dapat ditemui di wilayah lain dan masih terjaga eksistensi serta kelestariannyanya hingga sekarang.

Obyek penelitian dalam penelitian ini adalah bagaimana nilai-nilai kearifan lokal masyarakat Suku Anak Dalam pada karnaval Hari Kemerdekaan di Kecamatan Renah Pamenang.

Dalam penelitian ini teknik pengumpulan data yang dilakukan oleh peneliti adalah dengan melalui tiga metode, yaitu: (a) Wawancara, peneliti melakukan wawancara terhadap empat sumber yang berbeda, tujuannya adalah agar dapat menggali secara rinci data dan pengetahuan mengenai nilai-nilai kearifan lokal yang ada di Kecamatan Renah Pamenang; (b) Dokumentasi digunakan peneliti untuk mendukung hasil dari wawancara, dalam hal ini peneliti menggunakan dokumen berupa gambar pendukung dan Permendagri No.52 Tahun 2014 Tentang Pedoman Pengakuan dan Perlindungan Masyarakat Hukum Adat.

Dalam menganalisis data yang ditemukan menggunakan teknik analisis interaktif Milles dan Huberman yaitu dengan langkah-langkah: (a) Reduksi Data, penulis menganalisis penelitian ini dengan memilih narasumber, dengan pemokusan masyarakat Suku Anak Dalam sebagai narasumber utama. Setelah itu menyederhanakan hasil wawancara dengan narasumber serta berbagai data yang diperoleh agar hasil penelitian padat dan jelas; (b) Model data, analisis penulis dengan teknik ini dilakukan melalui pembuatan tabel display hasil wawancara dengan narasumber yang terkait.Selain itu, penulis juga melakukan display untuk mendeskripsikan kesimpulan wawancara tersebut menjadi hasil penelitian; (c) penarikan kesimpulan, berbagai data dan informasi yang diperoleh penulis dan telah diolah menghasilkan sebuah hasil akhir.

Dalam penelitian kualitatif, penyajian data bisa dilakukan dalam bentuk uraian atau deskriptif, bagan, hubungan antar kategori, dan sejenisnya Sugiyono (2017). Penyajian data akan memudahkan pembaca untuk memahami apa yang terjadi selama penelitian berlangsung. Dalam penelitian ini, peneliti akan menguraikan "Studi Tentang Nilai-Nilai Kearifan Lokal Masyarakat Suku Anak Dalam di Kecamatan Renah Pamenang, Kabupaten Merangin, Jambi". 


\section{Hasil dan Pembahasan}

\section{Persepsi Masyarakat Mengenai Kearifan Lokal}

Kearifan lokal menjadi salah satu hal penting dalam kehidupan warga negara Indonesia yang beraneka ragam. Kearifan lokal setiap daerah tentu memiliki karakteristik yang mencerminkan pandangan hidup masyarakat di daerah itu. Berdasarkan penelitian yang penulis lakukan, ada beberapa persamaan dan perbedaan persepsi antar masyarakat mengenai kearifan lokal. Seperti hasil wawancara penulis mengenai pengertian tentang kearifan lokal kepada KS (48 tahun), selaku Pejabat Renah Pamenang menjelaskan bahwa kearifan lokal merupakan adat yang dimiiliki suatu kelompok tertentu dan menjadi kebiasaan dan cirikhas mereka. Kebiasaan yang dilakukan oleh suatu kelompok tentu akan beralih menjadi pedoman dalam hidupnya. Oleh sebab itu, perilaku yang dilakukan oleh kelompok tersebut akan menampakkan sebuah cirikhas yang menjadi penanda keberadaan mereka. Sementara itu, Ketua Adat Suku Anak Dalam di Kampung Duren, Renah Pamenang, yakni Tumenggung JH (40 tahun) memberikan pengertian lain mengenai kearifan lokal, ia beranggapan bahwa kearifan lokal biasa disebut sebagai adat istiadat, yakni kebiasaan turun-temurun yang harus dilestarikan. Hal itu sejalan pula dengan yang dikatakan oleh $\mathrm{AB}$ (35 tahun), seorang penonton karnaval yang menyatakan pendapatnya bahwa kearifan lokal merupakan karakter dan tradisi masyarakat lokal yang melekat dari generasi ke generasi. Pendapat kedua responden tersebut senada dengan pendapat yang dikemukakan Hidayanti (2016) yang menyatakan bahwa kearifan lokal adalah seperangkat pengetahuan, norma, peraturan dan keterampilan masyarakat di suatu wilayah. Tujuan dibuatnya aturan tersebut adalah untuk memenuhi kebutuhan (hidup) bersama yang diwariskan secara turun temurun. Berdasarkan pemaparan di tersebut, dapat disimpulkan bahwa kearifan lokal merupakan adat, tradisi, kebudayaan, atau kebiasaan yang dilakukan secara turun-temurun yang melekat pada suatu suku atau kelompok di daerah tertentu dan dilestarikan dari generasi ke generasi.

Melestarikan kearifan lokal dari generasi ke generasi tentu bukan hal yang mudah. Banyak tantangan yang dihadapi masyarakat adat saat ini untuk menjaga kearifan lokal yang mereka miliki. Oleh sebab itu, upaya pelestarian kearifan lokal harus dilakukan dengan cara yang tepat. Ada beberapa pernyataan informan mengenai cara yang tepat dalam upaya pelestarian kearifan lokal. KS (48 tahun) memberikan pernyataan mengenai upaya pelestarian kearifan lokal, yakni dengan pendekatan kepada generasi selanjutnya supaya mereka tidak melupakan adat istiadat mereka. Selaras dengan hal itu, IF (22 tahun) menyatakan bahwa pelestarian kearifan lokal dapat dengan memperkenalkan budaya tersebut dan membuatnya menarik.

Salah satu pengupayaan pelestarian kearifan lokal ialah dengan memberi pemahaman dari suatu pengalaman yang panjang dengan pengamatan secara langsung atau disebut learning by experience yang dipertahankan dari generasi ke generasi (Pattinama 2019). Pemahaman tentang kearifan lokal harus ditanamkan secara dini kepada generasi selanjutnya. Sebab, pemahaman tersebut akan terus berkembang sehingga mereka memiliki dasar yang cukup kuat untuk terus melestarikan kearifan lokal yang ada.

Responden $\mathrm{AB}$ (35 tahun) dan JH (40 tahun) berpendapat bahwa kearifan lokal dapat terus dilestarikan apabila diberlakukan hukum sosial/hukum adat terhadap pelanggaran yang terjadi terkait dengan masalah-masalah kesukuan. Dengan begitu, mereka akan berperilaku sesuai dengan pedoman mereka dan tidak melakukan perbuatan yang melenceng dari kearifan lokal yang berlaku. Hal tersebut sejalan dengan pendapat Sukmayadi (2016), yang menyatakan bahwa kearifan lokal merupakan konsepsi umum dari kebijakan setempat (local wisdom), pengetahuan setempat (local knowledge) atau kecerdasan setempat (local genious). Konsepsi awal kearifan lokal merupakan kebijakan setempat. Artinya, kearifan lokal dibuat berdasarkan kebijakan yang disesuaikan dengan pengetahuan dan kecerdasan masyarakat setempat. Oleh karena itu, pemberian hukum atau sanksi adat kepada para pelanggar merupakan hal yang tepat. Jika pelanggar tidak mendapat sanksi/hukum adat maka sudah tidak ada lagi kebijakan setempat. Jika sudah tidak ada kebijakan setempat, maka kearifan lokal sudah tidak dapat dilestarikan lagi.

Berdasarkan pemaparan di atas, dapat ditarik kesimpulan sementara bahwa upaya pelestarian kearifan lokal dapat dilakukan melalui dua cara. Pertama, memberi pengenalan mengenai keraifan lokal di daerah tersebut dengan berbagai pendekatan kepada generasi selanjutnya. Kedua, Konsisten memberikan sanksi untuk pelanggaran terhadap hukum adat mereka.

\section{Unsur Kebudayaan Masyarakat Suku Anak Dalam di Kecamatan Renah Pamenang}

Setiap kebudayaan masyarakat yang ada di dunia akan terdapat tujuh unsur kebudayan yang merupakan inti dari kebudayaan masyarakat. Tak terkecuali pada masyarakat Suku Anak Dalam di Kecamatan Renah Pamenang. Sebagai makhluk sosial manusia saling berinteraksi satu dengan lainnya, yang lambat laun akan menghasilkan tata cara, prilaku serta pola hidup didalamnya. Jika digunakan dalam waktu yang lama akan menjadi kebiasaan, dan dari kebiasaan itu yang nantinya akan menjadi 
kebudayaan. Unsur-unsur kebudayaan masyarakat Suku Anak Dalam di Kecamatan Renah Pamenang dapat dijelaskan sebagai berikut.

1. Sistem Bahasa

Orang Rimba menggunakan bahasa Melayu Tua. Mereka mengenal dan fasih menggunakan bunyi sengau atau ucapan ke pangkal lidah dan hidung. Bahasa Orang Rimba adalah varian dari bahasa Melayu. Bahasanya serumpun dengan bahasa Minangkabau dan Melayu Jambi (Somad 2003). Seiring dengan perkembangan zaman dan terbukanya masyarakat Suku Anak Dalam terhadap masyarakat luar, saat ini mereka juga sering menggunakan bahasa Indonesia dengan campuran Melayu Jambi.

2. Sistem Pengetahuan

Orang Rimba memiliki cara yang khas dalam memahami dunia sekitar yang merupakan hasil dari interaksinya dengan alam dan kelompok manusia lainnya selama ribuan tahun. Mereka mengembangkan dunia batin yang cocok dan sesuai dengan kondisi mereka. Dunia batin itu memengaruhi cara mereka dalam memahami sesuatu dan dalam bertindak. Ide tentang dunia atau dunia batin mewujudkan dirinya dalam bentuk riil yakni sistem kepercayaan, mitos, adat, struktur sosial, dan psikologis. Hal tersebut sesuai dengan pernyataan JH (40 tahun) yang menjelaskan bahwa komunikasi dengan warga luar tergantung hati mereka yang merasakan, apakah baik atau tidak. Berdasarkan hal tersebut, maka dapat diketahui bahwa masyarakat Suku Anak Dalam tidak terlalu mengandalkan data di lapangan.

3. Sistem Sosial

Masyarakat Suku Anak Dalam memiliki susunan organisasi yang mengatur tingkat kekuasaan atau jabatan seseorang dalam wilayah mereka yang akan dijabarkan dalam hierarki berikut ini.

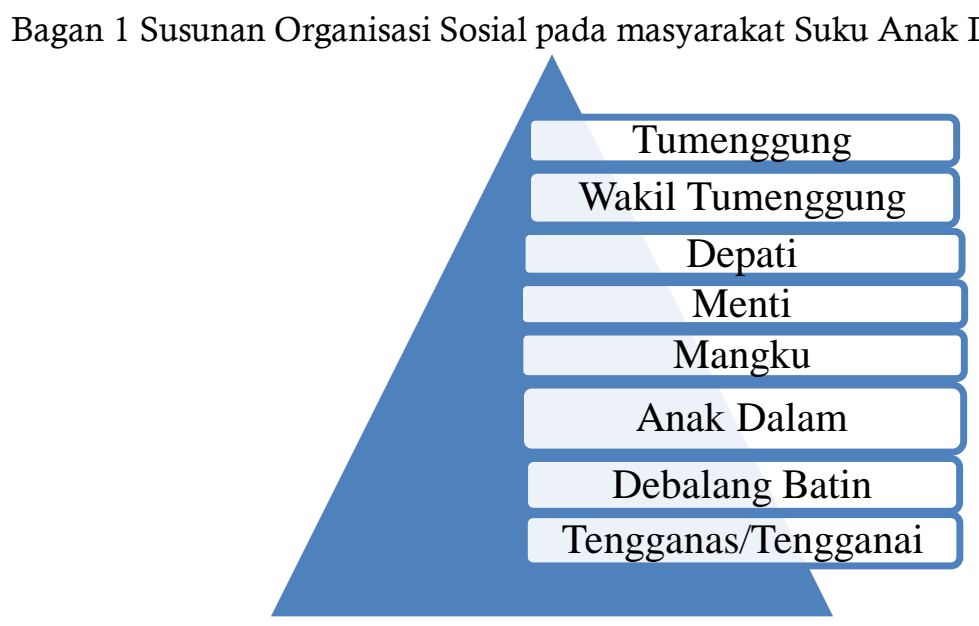

Sumber : Khotimah (2018)

Tumenggung merupakan Kepala Adat/Kepala Masyarakat, Wakil Tumenggung merupakan pengganti Tumenggung jika berhalangan melakukan tugas. Kepemimpinan Tumenggung diawasi oleh Depati. Jika terjadi suatu permasalahan, biasanya masyarakat Suku Anak Dalam akan menempuh hukum adat melalui sidang adat. Menti sebagai hakim bertugas untuk mengadili orang dengan cara adat. Sesangkan Mangku bertugas sebagai penimbang keputusan adat. Pada saat itu, Tumenggung dijemput oleh Anak Dalam menuju sidang adat dengan di kawal oleh oleh Debalang Batin agar tidak terjadi hal-hal yang tidak diinginkan. Keputusan akhir sidang diputuskan oleh Tengganas/ Tengganai sebagai pemegang keputusan tertinggi dalam sidang adat, dengan hak bisa membatalkan keputusan.

4. Sistem Peralatan Hidup dan Teknologi

Menurut Prasetijo (2011), sistem peralatan hidup dan teknologi Orang Rimba menggunakan kecepek, senapan yang dibuat sendiri dari pipa, atau kujur "tombak" untuk berburu hewan seperti babi hutan, rusa, kijang, kancil, dan labi-labi. Hal ini sesuai dengan apa yang ditampilkan masyarakat Suku Anak Dalam pada saat karnaval Hari Kemerdekaan. Mereka membawa tombak yang merepresentasikan alat yang mereka gunakan untuk bertahan hidup.

5. Sistem Mata Pencaharian

Sistem mata pencaharian hidup Orang Rimba adalah dengan meramu dan mengumpulkan sumber daya hasil hutan dengan tujuan diperjualbelikan dengan masyarakat luar. Mereka juga mencari ikan dan berburu (Prasetijo 2011). Hal tersebut sesuai dengan pernyataan responden KS (48 tahun) dan IF (22 tahun), berpendapat bahwa kehidupan mereka (Suku Anak Dalam) masih mencari makan dengan 
betilik (berburu). Pakainnya pun masih seperti nenek moyang mereka dahulu. Selain itu masih ada hukum adat yang masih dijalankan.

6. Sistem Religi

Sistem religi atau kepercayaan Orang Rimba adalah dinamisme dan animisme. Mereka memercayai kekuatan alam. Mereka memuja roh nenek moyang. Mereka memiliki banyak Dewa yang mereka anggap Tuhan. Akan tetapi mereka sesungguhnya tidak benar-benar bertuhan. Mereka benarbenar masih merupakan masyarakat primitif (Prihatini 2007). Akan tetapi, masyarakat Suku Anak Dalam di Kecamatan Renah Pamenang pun sekarang sudah ada yang memiliki kepercayaan terhadap Tuhan, dan hal tersebut memang diperbolehkan dalam adat mereka.

7. Sistem Kesenian

Kesenian yang dimiliki masyarakat Suku Anak Dalam umumnya berbentuk seni kerajinan dan keterampilan. Hal itu diperkuat dengan adanya peralatan dan perhiasan yang merupakan hasil dari tangan mereka sendiri.

Masyarakat Suku Anak Dalam memiliki unsur-unsur kebudayaan yang melekat pada dirinya. Tidak hanya sebagai penunjuk identitas, kebudayaan tersebut juga merupakan hasil dari kebiasaan yang menjadi gaya hidup mereka. Kebudayaan yang ada yang memiliki sisi positif harus terus dilestarikan.

\section{Nilai-Nilai Kearifan Lokal Suku Anak Dalam pada Karnaval Hari Kemerdekaan di Kecamatan Renah Pamenang}

Keberlangsungan kearifan lokal akan tercermin dalam nilai-nilai yang berlaku dalam kelompok masyarakat tertentu. Nilai- nilai itu menjadi pegangan kelompok masyarakat tertentu yang biasanya akan menjadi bagian hidup tak terpisahkan yang dapat diamati melalui sikap dan perilaku mereka sehari-hari. Nilai-nilai kearifan lokal Masyarakat Suku Anak Dalam pada karnaval Hari Kemerdekaan di Kecamatan Renah Pamenang tercermin pada:

1. Kostum / Pakaian

Pakaian yang digunakan masyarakat Suku Anak Dalam saat karnaval ialah menggunakan kain jarik. Laki-laki menggunakan kain jarik yang dililitkan di pinggang sedemikian rupa sehingga menutupi daerah depan dan belakang bagian bawah tubuhnya. Selain itu, mereka tidak menggunakan baju (bertelanjang dada). Perempuan Suku Anak Dalam tampil dengan pakaian dari kain jarik, sama seperti laki-laki. Namun, penggunaannya berbeda. Jika pada laki-laki kain jarik hanya menutupi bagian bawah tubuhnya, maka pada perempuan kain jarik dililit sedemikian rupa untuk menutupi tubuhnya dari leher hingga kaki tanpa menggunakan peniti. Pakaian yang ditampilkan masyarakat Suku Anak Dalam pada saat karnaval disepakati atas keinginan mereka sendiri yang ingin memperlihatkan keseharian mereka kepada masyarakat umum.

2. Aksesoris

Aksesoris yang digunakan masyarakat Suku Anak Dalam pada saat karnaval adalah kalung biji buah Sebelik Sumpah. Pohon Sebelik Sumpah adalah jenis tanaman pohon keras, yang biji buahnya dapat dimanfaatkan sebagai perhiasan oleh Suku Anak Dalam. Biasanya biji sebelik sumpah dijadikan perhiasan berupa kalung dan gelang. Berdasarkan penuturan JH (40 tahun), ia menyatakan bahwa kalung Sebelik Sumpah digunakan sudah sejak dahulu. Karena jika dipakai masyarakat dapat menangkal bala (tolak bala), jadi terhindar dari orang yang berniat jahat.

3. Atribut Tambahan

Perlengkapan atau atribut tambahan yang digunakan adalah tombak sebagai alat berburu yang dikenakan oleh laki-laki dan wadah hasil tani yang digunakan oleh perempuan. Pemilihan tombak dan ambung untuk ditampilkan saat karnaval merupakan pilihan yang sudah cukup merepresentasikan diri mereka. Hal itu bermakna bahwa sampai sekarang mereka masih hidup dengan cara tradisional, menggunakan alat-alat yang masih tradisional. Fungsi tombak tersebut adalah untuk berburu hewan darat atau hewan air di hutan sebagai makanan utama mereka.

Berdasarkan penampilan masyarakat pada saat karnaval, nilai-nilai kearifan lokal masyarakat Suku Anak Dalam pada karnaval Hari Kemerdekaan Republik Indonesia di Kecamatan Renah Pamenang diantaranya sebagai berikut.

1. Nilai Spiritual

Menurut Kamus Besar Bahasa Indonesia (KBBI), spiritual berasal dari kata spirit yang berarti "semangat, jiwa, roh, sukma, mental, batin, rohani dan keagamaan". Nilai spiritual Suku Anak Dalam pada saat karnaval tercermin dalam penggunaan kalung Sebelik Sumpah oleh masyarakat Suku Anak Dalam. kalung Sebelik Sumpah pada pembuatannya membutuhkan waktu yang sangat lama. Selain karena bijinya yang keras dan susah didapat, pengambilan biji Sebelik Sumpah disertai dengan doa- 
doa yang dipanjatkan sesuai kepercayaannya. Oleh sebab itu, kalung Sebelik Sumpah dipercaya memiliki kekuatan spiritual untuk menolak bala.

2. Nilai Moral/Kesopanan

Lickona (2016) mengungkapkan, ada 2 nilai yang menjadi nilai moral yang paling dasar yaitu sikap hormat dan tanggung jawab. Dari kedua nilai dapat membentuk inti dari masyarakat umum secara universal. Nilai moral atau nilai kesopanan tercermin pada pakaian yang digunakan masyarakat Suku Anak Dalam. Dulu, masyarakat Suku Anak Dalam beraktivitas hanya menggunakan cawat (celana dalam) untuk pria dan bawahan untuk wanita. Namun, sekarang masyarakat Suku Anak Dalam menggunakan pakaian yang lebih tertutup sebab untuk mereka lebih membuka diri kepada masyarakat sekitar. Hal itu menunjukkan adanya kesopanan masyarakat Suku Anak Dalam terhadap penduduk luar.

3. Nilai Kesederhanaan

Dalam Kamus Besar Bahasa Indonesia (KBBI), kesederhanaan adalah hal (keadaan, sifat). Kesederhanaan kata dasarnya adalah sederhana, yang berarti bersahaja; tidak berlebih-lebihan. Kesederhanaan merupakan sikap yang tidak terlalu dan berlebihan, dalam arti harus bersikap sewajarnya saja. Nilai kesederhanaan Suku Anak Dalam pada saat karnaval terlihat dari pakaian mereka. Mereka berpakaian hanya dengan sebuah kain jarik, namun dapat menutupi bagian tubuh yang merupakan aurat bagi mereka. Kain tersebut pun penggunaannya hanya dengan dililitkan, tidak memerlukan peniti atau ikat pinggang. Hal itu menunjukkan bahwa mereka sangat sederhana dan efisien.

4. Nilai Keteguhan dan Ketaatan

Keteguhan artinya kuat berpegang pada sesuatu, tidak goyah dihadapkan dengan suatu pengaruh atau pilihan dalam hidupnya (Rahma et al. 2013). Nilai keteguhan dan Ketaatan tercermin pada penggunaan aksesoris berupa kalung Sebelik Sumpah pada saat karnaval. Penggunaan kalung tersebut memang merupakan tradisi turun-temurun dari nenek moyang mereka. Setiap anak yang lahir akan dibuatkan aksesoris dari biji buah Sebelik Sumpah. Hal ini menunjukkan bahwa mereka masih berpegang teguh dan taat pada adat yang mereka miliki.

5. Nilai Gotong Royong

Gotong royong merupakan bagian dari etika sosial dan budaya yang bertolak dari rasa kemanusiaan. Nilai gotong royong dan solidaritas masyarakat Suku Anak Dalam tercermin pada perlengkapan yang mereka bawa pada saat karnaval. Laki-laki membawa tombak sebagai alat berburu sedangkan perempuan membawa ambung sebagai wadah hasil tani. Ini menunjukkan bahwa antara laki-laki dan perempuan saling bergotong-royong melakukan tugas sesuai dengan porsinya masing-masing untuk mencukupi kebutuhan hidup mereka.

6. Nilai Cinta Lingkungan

Nilai cinta alam dan lingkungan terlihat dari semua hal yang mereka tampilkan. Mereka memilih kain jarik saja sebagai pakaiannya, sehingga tidak menimbulkan banyak limbah tekstil. Masyarakat Suku Anak Dalam memakai perhiasan dari pohon Sebelik Sumpah dengan memilih (tidak sembarangan) sehingga tidak merusak pohon tersebut. Selain itu perlengkapan yang mereka bawa merupakan produk ramah lingkungan.

7. Nilai Kemanfaatan

Nilai kemanfaatan dapat dilihat dari semua hal yang ditampilkan masyarakat Suku Anak Dalam. Dari segi pakaian, mereka memakai kain jarik karena melihat dari sisi manfaat, bukan sekedar visual atau menarik perhatian. Dari segi aksesoris, mereka menggunakan kalung Sebelik Sumpah karena bermanfaat untuk menolak bala sesuai kepercayaan mereka. Dari segi perlengkapan, mereka memanfaatkan apa yang tersedia di alam untuk keperluan hidup mereka.

8. Nilai Kesadaran Hukum

Tampilan masyarakat Suku Anak Dalam pada karnaval juga mencerminkan nilai kesadaran hukum. Diantaranya adalah pada penggunaan tombak sebagai alat berburu. Mereka menyadari bahwa menggunakan senjata api untuk berburu adalah pelanggaran hukum. Oleh sebab itu, meskipun sempat mencoba menggunakan senjata api akhirnya mereka memilih untuk menggunakan tombak saja dan kembali menggunakan tombak.

9. Nilai Cinta Tanah Air

Menurut Suyadi (2013), cinta tanah air merupakan sikap dan perilaku yang mencerminkan nasionalisme, patriotisme dan penghargaan yang tinggi terhadap berbagai aspek yang dimiliki bangsanya yang timbul dari hati seseorang warga negara, sehingga tidak akan terpengaruh dengan iming-iming bangsa lain yang dapat merugikan bangsa sendiri sehingga menimbulkan keinginan untuk mengabdi, memelihara, melindungi bangsa dan negaranya dari segala ancaman dan gangguan yang dapat merusak. Nilai cinta tanah air masyarakat Suku Anak Dalam tercermin pada keikutsertaan 
mereka pada Upacara Bendera dan kegiatan karnaval Hari Kemerdekaan Republik Indonesia. Mereka sadar akan identitasnya sebagai Warga Negara Indonesia, maka mereka secara sadar mau berpartisipasi dalam kegiatan tersebut. Tidak ada paksaan atau intervensi dari luar, sehingga hal ini murni merupakan ungkapan bentuk cinta tanah air mereka.

Berdasarkan berbagai pemaparan di atas, dapat disimpulkan bahwa nilai-nilai kearifan lokal masyarakat yang tercermin pada kegiatan karnaval Hari Kemerdekaan Republik Indonesia di Kecamatan Renah Pamenang adalah nilai spiritual, nilai moral dan kesopanan, nilai kesederhanaan/efisiensi, nilai keteguhan dan ketaatan, nilai gotong royong dan solidaritas, nilai cinta lingkungan, nilai kemanfaatan, nilai kesadaran hukum, dan nilai cinta tanah air.

\section{Kesimpulan}

Berdasarkan berbagai pemaparan di atas, maka dapat disimpulkan sebagai berikut.

1. Kearifan lokal merupakan adat, tradisi, kebudayaan, atau kebiasaan yang dilakukan secara turuntemurun yang melekat pada suatu suku atau kelompok di daerah tertentu dan dilestarikan dari generasi ke generasi. Upaya pelestarian kearifan lokal dapat dilakukan melalui dua cara. Pertama, memberi pengenalan mengenai keraifan lokal di daerah tersebut dengan berbagai pendekatan kepada generasi selanjutnya. Kedua, Konsisten memberikan sanksi untuk pelanggaran terhadap hukum adat mereka.

2. Unsur-Unsur Kebudayaan yang ada pada masyarakat Suku Anak Dalam di Kecamatan Renah Pamenang adalah sistem bahasa (Bahasa Melayu, Bahasa Minangkabau, dan Bahasa Indonesia), sistem pengetahuan (pengembangan batin), sistem sosial (berdasarkan kekuasaan), sistem peralatan hidup dan teknologi (peralatan dari hutan), sistem mata pencaharian (berburu dan meramu), sisem religi (domnan animisme dan dinamisme), dan sistem kesenian (keterampilan dan kerajinan tangan).

3. Penampilan masyarakat Suku Anak Dalam saat karnaval tercermin dalam bentuk:

4. Pakaian. 2) Aksesoris. 3) Atribut. Nilai kearifan lokal masyarakat yang tercermin pada kegiatan karnaval Hari Kemerdekaan Republik Indonesia di Kecamatan Renah Pamenang adalah nilai spiritual, nilai moral dan kesopanan, nilai kesederhanaan/efisiensi, nilai keteguhan dan ketaatan, nilai gotong royong dan solidaritas, nilai cinta lingkungan, nilai kemanfaatan, nilai kesadaran hukum, dan nilai cinta tanah air.

\section{Daftar Pustaka}

Anas, Ajrul. 2015. "Analisis Dampak Globalisasi Terhadap Lunturnya Nilai-Nilai Budaya Sebagai Kearifan Lokal Masyarakat Di Desa Rai-Oi, Kecamatan Sape, Kabupaten Bima."

Baharudin, Erwan. 2010. "Pendidikan Suku Anak Dalam: Suatu Perubahan Dari Paradigma Positivistik Ke Kontruktivisme." Forum Ilmiah 7 (2).

Hidayanti, Deny. 2016. "Memudarnya Nilai Kearifan Lokal Masyarakat Dalam Pengelolaan Sumber Daya Air." Jurnal Kependudukan Indonesia 11(1):39-48.

Khotimah, Khusnul. 2018. Manajemen Pembinaan Pendidikan Pada Masyarakat Suku Anak Dalam Di Pematang Kolim Gurun Tuo, Mandiangin, Sarolangun. Surakarta.

Lickona, Thomas. 2016. Educating for Character (Mendidik Untuk Membentuk Karakter). Pertama. edited by U. Wahyudin. Jakarta: Bumi Aksara.

Pattinama, Marcus J. 2019. "Pengentasan Kemiskinan Dengan Kearifan Lokal (Studi Kasus Di Pulau Buru- Maluku Dan Surade-Jawa Barat." Sosial Humaniora 13(1):1-12.

Prasetijo, Adi. 2011. Serah Jajah Dan Perlawanan Yang Tersisa, Etnografi Orang Rimba Di Jambi. 1st ed. Jakarta: Wedatama Widya Sastra.

Prihatini, Dini. 2007. KebudayaanSuku Anak Dalam. Yogyakarta.

Rahma, Awiya, Galuh Kusuma Wati, Ahmad Kamal Idris, Muhammad Irfan, and Moordiningsih. 2013. "Pengaruh Keteguhan Hati Dalam Kehidupan Sosial, Budaya Dan Agama: Tinjauan Psikologi Islam Dan Psikologi Indegeneus." Pp. 512-26 in Islam dan Peradaban Umat. Surakarta: Universitas Muhammadiyah Surakarta.

Somad, Kemas Arsyad. 2003. "Mengenal Adat Jambi Dalam Persfektif Modern." Dinas Pendidikan Provinsi Jambi.

Sugiyono. 2017. Metode Penelitian Bisnis: Pendekatan Kuantitatif, Kualitatif, Kombinasi, Dan R\&D. Bandung: CV. Alfabeta.

Sukmayadi, Trisna. 2016. "Kajian Tentang Karakter Berbasis Nilai-Nilai Kearifan Lokal Pada Masyarakat Adat Kampung Kuta Kecamatan Tambaksari Kabupaten Ciamis." Jurnal Civics: Media Kajian Kewarganegaraan 13(1):96-112.

Suyadi. 2013. Strategi Pembelajaran Pendidikan Karakter. Bandung: Remaja Rosdakarya. 